\title{
E-portfolio Assessment System for an Outcome- Based Information Technology Curriculum
}

\author{
Abdallah Tubaishat and \\ Azzedine Lansari \\ Zayed University, Abu Dhabi, UAE
}

\author{
abdallah.tubaishat@zu.ac.ae; \\ azzedine.lansari@zu.ac.ae
}

\author{
Akram Al-Rawi \\ McKendree University, \\ Lebanon, IL, USA
}

amal-rawi@mckendree.edu

\section{Executive Summary}

Currently colleges and universities are facing a number of problems, including ill designed curricula that do not address demands from the job market. There is also tremendous pressure from society on academic institutions to provide an education that results in guaranteed employment, especially given the soaring price of higher education. Currently, a number of academic institutions are facing the problem of grade inflation, which has resulted in the grade point average (GPA) model losing its value (Mansfield, 2001). Therefore, academic educational institutions are looking for alternative ways to provide an education that attracts students in a highly competitive world. Several US academic institutions have adopted the outcome based educational model to move away from the GPA driven model. Furthermore, accreditations organizations (such as North Central Association of Colleges and Schools) are requiring academic institutions to present a method to assess students' learning outcomes, particularly in the general education courses.

The purpose of this study is to report on lessons learned from the early stages of implementing an e-portfolio assessment system using an outcome-based information technology curriculum. As a college requirement, students need to develop an e-portfolio to showcase significant work and demonstrate progress toward achieving college learning outcomes. The student e-portfolio includes a variety of digital artifacts such as projects, term papers, or case studies. The e-portfolio assessment system was developed to facilitate the assessment of student work. This system includes a repository of student work, faculty assessment criteria, and course specific learning outcomes, and allows faculty to post comments on student work. Students can then review their work and decide whether to include it in their e-portfolios. The College developed an alignment model to map all learning outcomes into courses of the curriculum. In this model, significant assignments are embedded in IT courses and are used to measure the achievement level of a particular outcome(s). In their final year, senior students present the latest version of their eportfolios to a faculty panel and explain their choice of each piece of evidence and how it links to

Material published as part of this publication, either on-line or in print, is copyrighted by the Informing Science Institute. Permission to make digital or paper copy of part or all of these works for personal or classroom use is granted without fee provided that the copies are not made or distributed for profit or commercial advantage AND that copies 1) bear this notice in full and 2) give the full citation on the first page. It is permissible to abstract these works so long as credit is given. To copy in all other cases or to republish or to post on a server or to redistribute to lists requires specific permission and payment of a fee. Contact Publisher@InformingScience.org to request redistribution permission. one or more college learning outcomes. It is anticipated that with time, student e-portfolios will become an important source of information for the College to evaluate the effectiveness of learning outcomes across the curriculum.

Keywords: e-portfolios, e-portfolio assessment system, outcome-based educational model, IT curriculum. 


\section{Introduction}

A major shift in the past decade has changed the focus in education from a teacher-centered instructional environment to a student-centered one (Brooks, 1997). As grades became insufficient to prove learning took place, universities in the USA and worldwide took a critical look at their educational systems. In 2002 a US national panel called for a dramatic reorganization of undergraduate education to ensure that all college students receive not only access to college but also to an education of lasting value (http://www.aacu.org). One recommendation was that colleges and universities help students become "intentional" life-long learners and create new assessment techniques that allow students to apply their learning to real world problems. In an effort to shift the focus from the traditional lecture style to a student-centered learning style, a number of academic institutions in the US have adopted an outcome-based education framework. Outcomebased education is a method of education that focuses on what students can actually do after they are taught a particular subject. All curriculum and teaching decisions are made based on how to best facilitate the achievement of a desired outcome. This exercise leads to a planning process that is quite different from the traditional educational planning method. The desired outcome is first identified, and then the curriculum is created to support the intended outcomes (Furman, 1994).

E-portfolios have been used to document student work to demonstrate learning (American Association for Higher Education. 2008, Smith \& Winking-Diaz, 2004). Unlike paper-based portfolios, e-portfolios allow information to be stored, accessed, updated, and presented in various electronic formats to record students achievements. E-portfolios are being adopted at a growing number of colleges and universities in the USA and abroad (Lorenzo \& Ittelson, 2005. Several US universities have adopted the e-portfolio assessment concept, including California Lutheran University (http://ww2.clunet.edu/soe/webfolio/index.php), Portland State University (http://www.pdx.edu/unst/frinq.htm), John Hopkins University(2008) (http://cte.jhu.edu/dp/support), the Connecticut Distance Learning Consortium (http://www.eportfolio.org), and Indiana University-Purdue University Indianapolis (http://www.opd.iupui.edu/coil/eport.htm). For faculty, the e-portfolio can be an effective tool to better manage, review, reflect, and comment on students' work. For students, the e-portfolio enriches their resume, both before and after graduation. In the gulf region the adoption of outcomebased educational models and e-portfolios has been slow. Zayed University (ZU), a fairly recent university located in the United Arab Emirates (UAE) has adopted an outcome-based Academic Program Model (APM) and the use of e-portfolios to document student learning (Zayed University, 2008a). The ZU e-portfolio assessment system (EAS) was created to allow faculty to assess specific components of student academic work that includes various learning outcomes. Moreover, faculty members use data from the EAS to evaluate how courses are meeting college and university goals. The achievement of learning outcomes and the compilation of e-portfolios has become an important component of the grade point average (GPA) assessment system. Eportfolios enable students to improve and focus their learning and provide them with a tool to showcase their skills. The EAS can be used to measure whether the curriculum meets institution and college/major learning outcomes: Zayed University Learning Outcomes (ZULOs), and Major's Learning Outcomes (MALOs).

Currently, ZU has approximately 4000 students and has two campuses, one in Abu Dhabi and one in Dubai, UAE. ZU follows a US based academic model and is perhaps the first university in the Gulf to adopt the e-portfolio to help students achieve learning. During the last six years, the implementation of the APM model was used to facilitate the inclusion of learning outcomes into various courses across $\mathrm{ZU}$ curricula. 


\section{Learning Environment at Zayed University}

ZU was established in 1998 and had the opportunity to build upon best practices from reputable US academic institutions. The university was established to provide a western-style higher educational model to national female students of the UAE. The University has five colleges, and most of the faculty members are graduated from universities in North America, Europe, and Australia. The university endeavors to provide students learning opportunities using the American style of education and learning to ensure high quality education.

ZU has an excellent technology infrastructure; its campuses are fully networked and allow students to connect to various university networks and the Internet from anywhere on campus. All the university has wired and wireless connections (classrooms, library, offices, student hubs, cafeteria, etc). Each student is required to purchase a laptop and each faculty member receives a laptop with a three-year replacement schedule.

Students have easy access to technology in order to facilitate the learning process. Actually, ZU is known as the laptop university in this region. In the College of Information Technology (CIT), students have their own laptop loaded with the necessary software for their courses. This helps them complete their work independently without having to be on campus all the time. The IT College has an independent network infrastructure for teaching and research, in addition to the university's main network. This infrastructure allows students to login remotely into Linux servers to use tools needed for programming languages, databases, and web development courses. Students can also use Linux-based communication tools to collaborate with each other and with instructors. All ZU courses are implemented on Blackboard, a learning management system. ZU students can access Blackboard from anywhere at any time using a web client.

ZU has adopted an outcome based learning framework to provide a strong focus to the students' learning outcomes and to improve both curriculum and learning practices. The APM was developed by faculty and emphasizes a commitment to a learner-based education and to shift the teaching paradigm to a student learning model. This model focuses on what students can actually do after they graduate. More details about this model can be found in the ZU internal report on "Self-Assessment Based on Accreditation Standards of the Middle States Commission on Higher Education" (Zayed University, 2008b), and the ZU Academic Program Model (Zayed University, 2008a).

The purpose of the outcome-based model is to provide students with a focused and coherent academic program and to prepare graduates for a rapidly changing and unpredictable future. It is outcome driven and uses the traditional Grade Point Average (GPA) system. The framework that constitutes the academic program model is composed of three components:

- Readiness program to ensure that students are competent in English language

- General Education

- Degree Major

A major objective of the undergraduate experience at $\mathrm{ZU}$ is the development of the skills necessary for continuous lifelong learning. The APM is designed to help achieve this objective by providing students with a foundation and framework for all university studies. Every ZU course focuses on one or more of the six university-specified learning outcomes. The learning outcomes are incorporated into normal course work and, therefore, are an integral part of disciplinary content and evaluation of the course. Threaded throughout the baccalaureate curriculum, the learning outcomes help students achieve a higher order of intellectual development. ZU has the following graduation requirements for all students regardless of their major (Zayed University, 2008a): 
- Information Literacy and Communication: ZU graduates will be able to recognize information needs, access and evaluate appropriate information to answer those needs, and communicate effectively to a variety of audiences in both English and Arabic.

- Information Technology: ZU graduates will be critically aware of the implications of information technology on the individual and on society and be able to use IT to communicate and solve problems in an ethical way.

- Critical Thinking and Quantitative Reasoning: ZU graduates will be able to use information, reasoning, and creative processes to achieve goals and make responsible decisions.

- Global Awareness: ZU graduates will be able to relate to communities beyond the local, perceive and react to differences from an informal and reasoned point of view, and be critically aware of the implications and benefits of cultural interaction.

- Teamwork and leadership: ZU graduates will be able to work efficiently and effectively in a group. ZU graduates will be able to assume leadership roles and responsibilities in a variety of life situations and accept accountability for the results.

- Bilingual: ZU graduates will be able to communicate effectively (orally and in writing) in both English and Arabic.

\section{CIT Outcome-Based Curriculum}

The CIT College offers three tracks: security, networking, and web technologies. Figure 1 shows the course sequence for each track. All core courses in each sequence include specific ZULOs and MALOs that are applicable to the course content.

The CIT College has established five learning outcomes that complement the learning outcomes of the ZU APM. These major learning outcomes form the basis for analysis and assessment that play an essential role in the continuous process of improvement. The major learning outcomes of the CIT College are as follows:

- Problem Identification and Analysis: CIT graduates will be able to organize, define, and classify problems.

- Problem Solving: CIT graduates will derive solutions and evaluate their success.

- Information Technology and their Application and Managements: CIT graduates will understand the capabilities, use, and application of information technologies.

- Systems Principles and Practices: CIT graduates will demonstrate understanding of system types, structure, standards, and metrics.

- Technical Communication: CIT graduates will organize, develop, present, and evaluate technical material.

The EAS provides an assessment framework in which key assignments are embedded into courses to measure the achievement of a particular learning outcome and to track key learning goals. The IT College completed its mapping of all learning outcomes across the IT curriculum during the 2006-2007 academic year. The resulting alignment course/outcome model is described in Table 1. The Appendix depicts an example of a master course syllabus that shows how ZULOs and MALOs are linked to each other.

The table shows the mapping of six ZULOs and five MALOs into all courses in the CIT curriculum. Moreover, for each outcome the expected student achievement level is described. Three achievement levels are used to demonstrate the student's accomplishment for each outcome. The 
beginning level demonstrates a basic understanding; the developing level demonstrates a more in depth understanding of concepts leading to the achievement of a given outcome. Finally, the accomplished level demonstrates proficiency in understanding of various concepts leading to the achievement of an outcome.

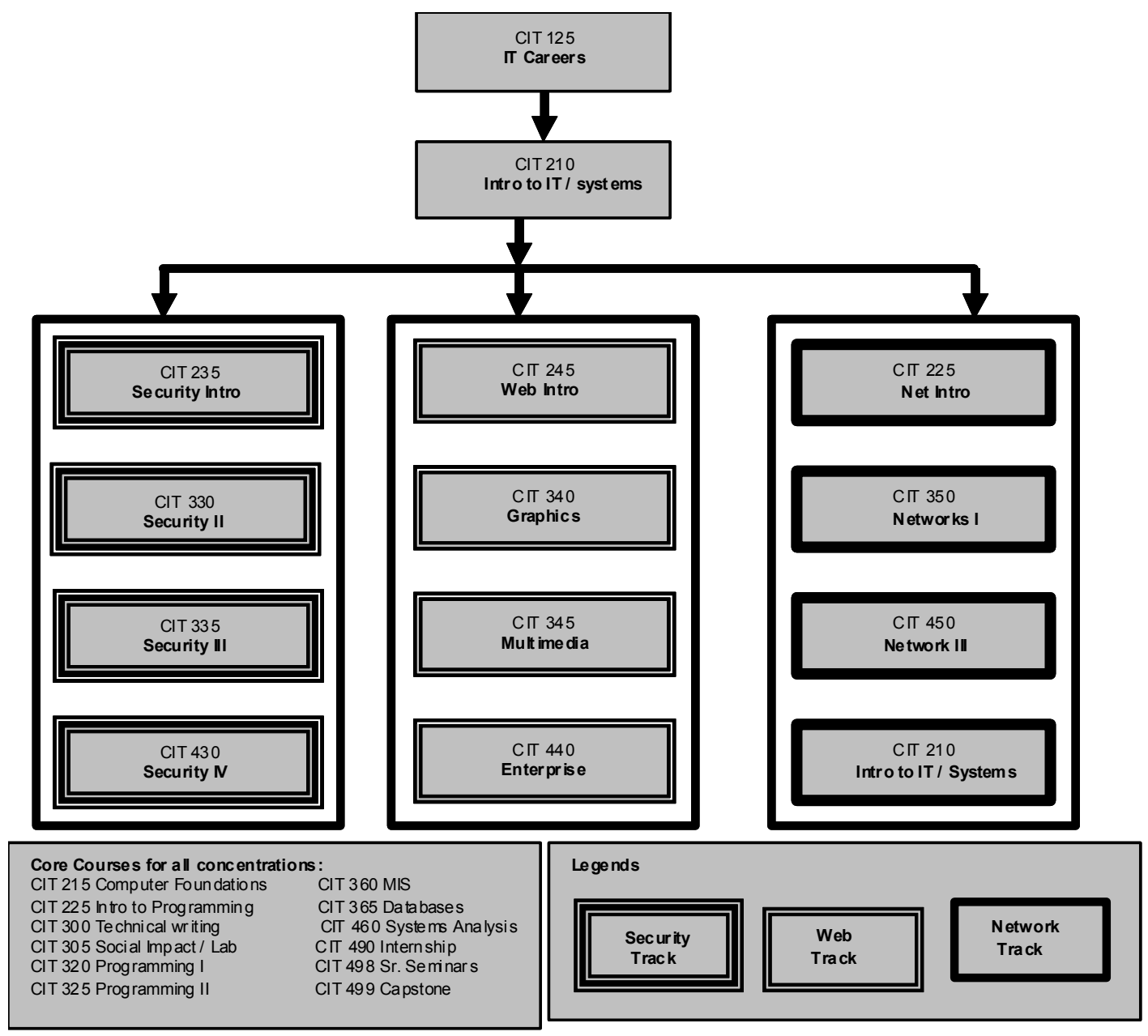

Figure 1 Information technology curriculum

\section{E-portfolio Assessment System in the IT College}

The EAS is an important resource used in the college for various assessment activities. The system is a searchable, electronic storage tool into which specific examples of student work are uploaded from various courses across the curriculum. Major student assignments, as identified in the master course syllabus to address a specific learning outcome(s), are uploaded into the EAS. The students' submissions are then rated by faculty. After reviewing student work, the faculty comments on the student's work and posts their feedback in a designated area of the EAS. Moreover, the faculty evaluates both the assignment's general effectiveness and its level of accomplishment with respect to the desired outcome(s). Students are able to access the faculty comments from the EAS, as well as any other work posted on the system. This process enables students to update their work and reflect on their learning. The EAS was designed to function as an archive for research on the effectiveness of various courses in achieving learning outcomes. Because all major student work is uploaded to the system, research into student achievement of learning outcomes in courses or sequences of courses can be easily carried out. Furthermore, student work can be sorted and studied either by course or by outcome. 
Table 1: CIT curriculum courses with learning outcomes and achievements levels

\begin{tabular}{|c|c|c|c|c|c|c|c|c|c|c|c|c|}
\hline \multirow[b]{2}{*}{1} & \multirow[b]{3}{*}{ CIT 125} & \multirow[b]{3}{*}{ Discovering IT } & \multicolumn{5}{|c|}{ ZULOs } & \multicolumn{5}{|c|}{ MALOs } \\
\hline & & & IT & GA & CTR & ILC & TL & PIA & PS & ITA & STP & TC \\
\hline 2 & & & $\mathrm{~B}$ & $\mathrm{~B}$ & & $\mathrm{~B}$ & & & & $\mathrm{~B}$ & & $\mathrm{~B}$ \\
\hline 3 & CIT 210 & Intro. to IT and Systems & $\mathrm{B}$ & & & $\mathrm{B}$ & & $\mathrm{B}$ & & $\mathrm{B}$ & & $\mathrm{B}$ \\
\hline 4 & CIT 215 & Comp. Foundations & & & $\mathrm{D}$ & & & $\mathrm{D}$ & $\mathrm{D}$ & & & \\
\hline 5 & CIT 225 & Intro. Prog/Prob Sol. & D & & $\mathrm{B}$ & & & $\mathrm{B}$ & $\mathrm{B}$ & & & \\
\hline 6 & CIT 235 & Info. Security Basics & $\mathrm{D}$ & $\mathrm{B}$ & $\mathrm{B}$ & $\mathrm{B}$ & & D & D & & & \\
\hline 7 & CIT 245 & Web Development & $\mathrm{D}$ & & & & & $\mathrm{D}$ & $\mathrm{D}$ & & & $\mathrm{D}$ \\
\hline 8 & CIT 255 & Networks/Telcomms & A & & & & $\mathrm{D}$ & & & $\mathrm{A}$ & & $\mathrm{D}$ \\
\hline 9 & CIT 270 & ICDL & D & & & & & & & & & $\mathrm{B}$ \\
\hline 10 & CIT 295 & Independent Studies & $\mathrm{A}$ & & & & & & & A & & D \\
\hline 11 & CIT 300 & Technical English & & & $\mathrm{D}$ & $\mathrm{D}$ & & $\mathrm{D}$ & & $\mathrm{D}$ & & A \\
\hline 12 & CIT 300AL & Arabic I & D & $\mathrm{D}$ & & D & & D & & A & & D \\
\hline 13 & CIT 305 & IT Local/Global Cultures & D & D & & D & & D & & A & & D \\
\hline 14 & CIT 305AL & Arabic II & D & $\mathrm{D}$ & & $\mathrm{D}$ & & $\mathrm{D}$ & & A & & $\mathrm{D}$ \\
\hline 15 & CIT 320 & Prog/Prob Sol. I & $\mathrm{D}$ & & $\mathrm{D}$ & & & $\mathrm{D}$ & D & & & $\mathrm{D}$ \\
\hline 16 & CIT 325 & Prog/Prob Sol. II & & & $\mathrm{D}$ & & & $\mathrm{D}$ & $\mathrm{D}$ & & & \\
\hline 17 & CIT 330 & Global Information Security & $\mathrm{D}$ & $\mathrm{D}$ & $\mathrm{B}$ & $\mathrm{B}$ & & & & $\mathrm{D}$ & $\mathrm{D}$ & $\mathrm{D}$ \\
\hline 18 & CIT 335 & Information Security Technologies & D & B & D & $\mathrm{D}$ & & D & $\mathrm{D}$ & & & \\
\hline 19 & CIT 340 & Computer Graphics & A & & A & & & & & A & & \\
\hline 20 & CIT 345 & Multimedia Systems & & & & & D & $\mathrm{D}$ & $\mathrm{D}$ & & & \\
\hline 21 & CIT 350 & Comm. Networks I & A & & & & $\mathrm{D}$ & & & A & & \\
\hline 22 & CIT 355 & Comm. Networks II & A & & & & $\mathrm{D}$ & & & A & & \\
\hline 23 & CIT 360 & Management of Information Systems & A & $\mathrm{B}$ & $\mathrm{D}$ & & & $\mathrm{D}$ & $\mathrm{D}$ & $\mathrm{A}$ & $\mathrm{D}$ & \\
\hline 24 & CIT 365 & Database Systems & A & & A & & & A & A & & & D \\
\hline 25 & CIT 395 & Independent Studies & A & & & & & & & A & & $\mathrm{D}$ \\
\hline 26 & CIT 430 & Information Security Management & $\mathrm{D}$ & $\mathrm{D}$ & $\mathrm{B}$ & D & & & & $\mathrm{D}$ & $\mathrm{D}$ & $\mathrm{D}$ \\
\hline 27 & CIT 440 & Enterprise Web Appl'ns & A & & & & & $\mathrm{D}$ & & $\mathrm{A}$ & & \\
\hline 28 & CIT 450 & Comm. Networks III & A & & $\mathrm{D}$ & & & & & $\mathrm{A}$ & & \\
\hline 29 & CIT 460 & Sys Analysis \& Design & D & & $\mathrm{D}$ & & & $\mathrm{D}$ & & & & $\mathrm{A}$ \\
\hline 30 & CIT 470 & Applied Database & A & & $\mathrm{D}$ & & & & A & & & $\mathrm{D}$ \\
\hline 31 & CIT 475 & IT Sys Development & $\mathrm{D}$ & & $\mathrm{D}$ & & & $\mathrm{D}$ & & & & $\mathrm{D}$ \\
\hline 32 & CIT 490 & Internship & D & & $\mathrm{D}$ & & & & $\mathrm{D}$ & & & $\mathrm{D}$ \\
\hline 33 & CIT 495 & Independent Studies & $\mathrm{A}$ & & & & & & & $\mathrm{A}$ & & $\mathrm{D}$ \\
\hline 34 & CIT 497 & Special Topics & A & & & & & & & $\mathrm{A}$ & $\mathrm{D}$ & \\
\hline 35 & CIT 498 & Senior Seminar & & & $\mathrm{D}$ & $\mathrm{A}$ & D & $\mathrm{A}$ & & & & $\mathrm{A}$ \\
\hline & CIT 499 & Capstone & & & D & A & D & A & & & & A \\
\hline
\end{tabular}

ZULOS:

IT - Information Technology

GA - Global Awareness

CTR - Critical Thinking and Reasoning

ILC - Information Literacy and Communication

TL - Teamwork and Leadership
MALOS:

PIA - Problem Identification and Analysis

PS - Problem Solving

ITA - Information Technology Applications

STP - Systems Theory and Practice

TC - Technical Communication

LEVELS B - Beginning D - Developing A - Accomplished 
Figure 2 shows the EAS interface. The interface shows for a particular faculty member the courses being taught as well as the assessment criteria posted by the instructor. It allows him/her to select term code and the courses in that semester through accessing e-portfolio systems via the Intranet or extranet.

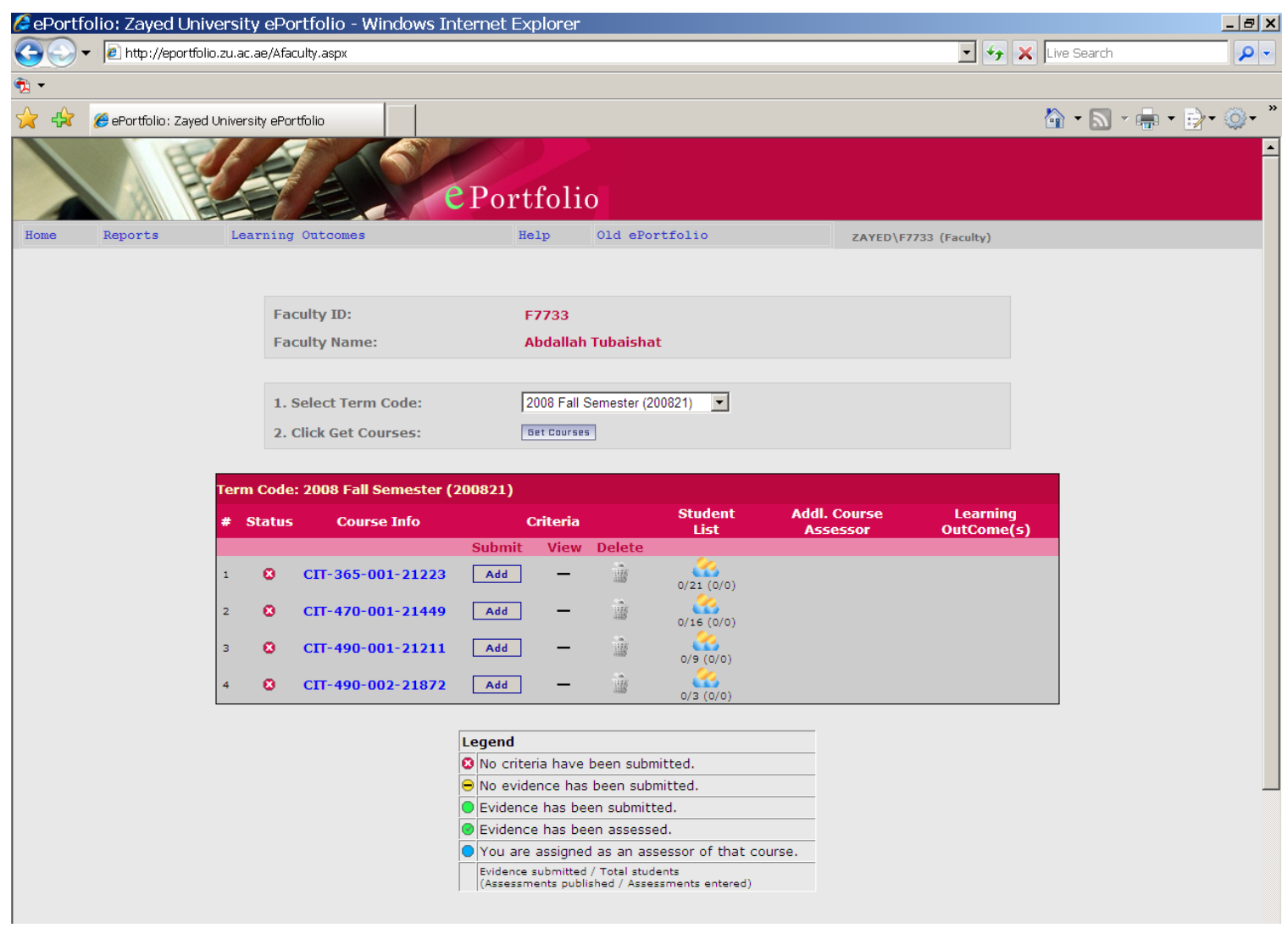

Figure 2: E-portfolio assessment system interface

After matching courses with learning outcomes, faculty members develop key assignments for the courses to optimize targeted learning. The assignments include a term paper, a lab exercise, a design for building a network, or a case study. Figure 3 shows another snapshot of the EAS where instructors have the ability to add, view, or delete the assessment criteria for the course being taught. Moreover, instructors can access student information for a specific course, as well as information about the learning outcomes. 


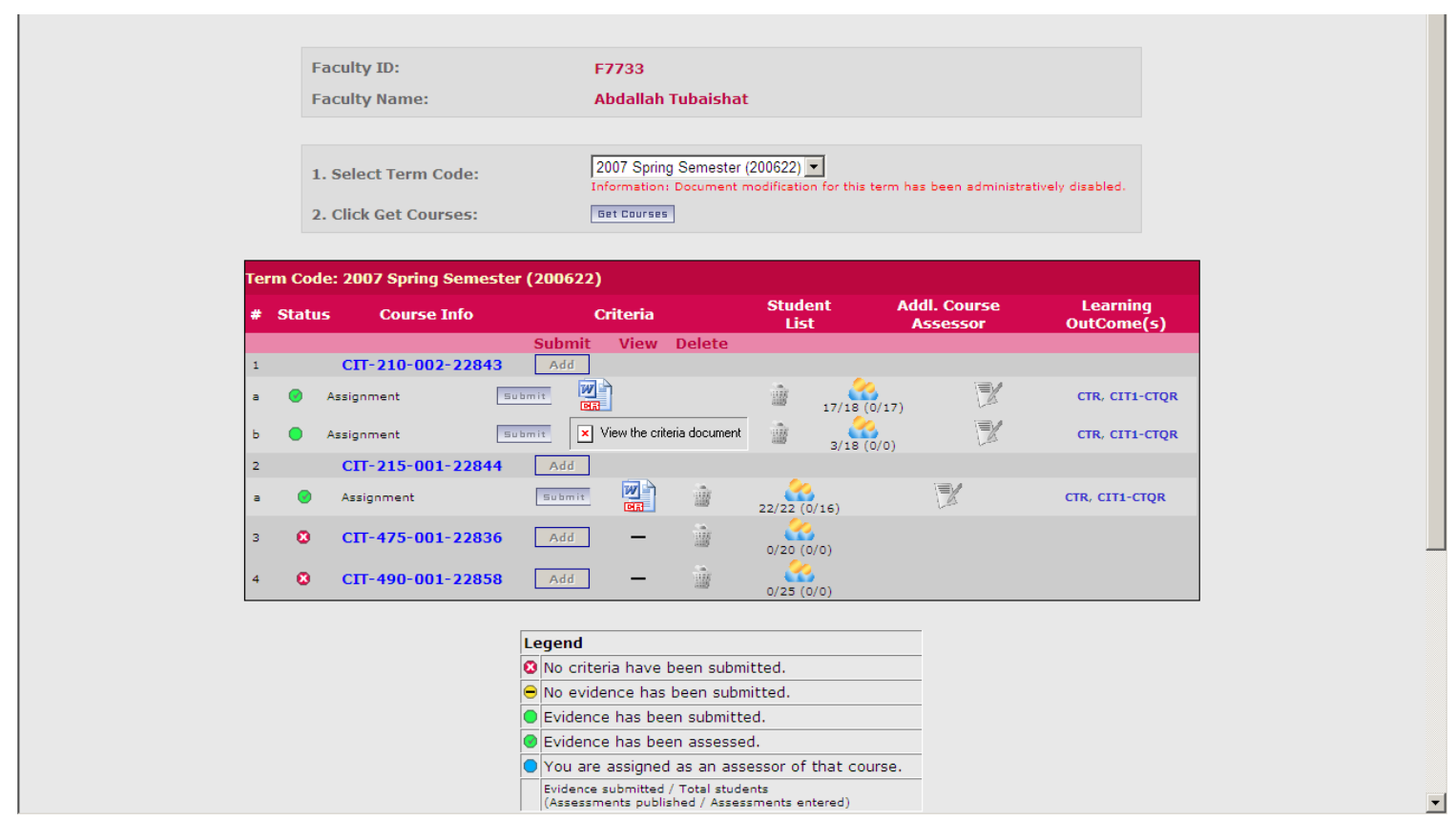

Figure: 3 EAS course information, related learning outcomes and assessment citeria

Figure 4 shows the list of all students registered in a particular course, as well as the the critera used for assesssing the learning outcome(s) in that course. For each student, the submitted piece of evidence is shown next to the assessment criteria. After grading the piece of evidence, the instructor posts the assessment feedback. The students can then access the instructor's assessment/feedback and modify their work. Finally, the students have the option to include that piece of evidence as an artifact in their e-portfolio.

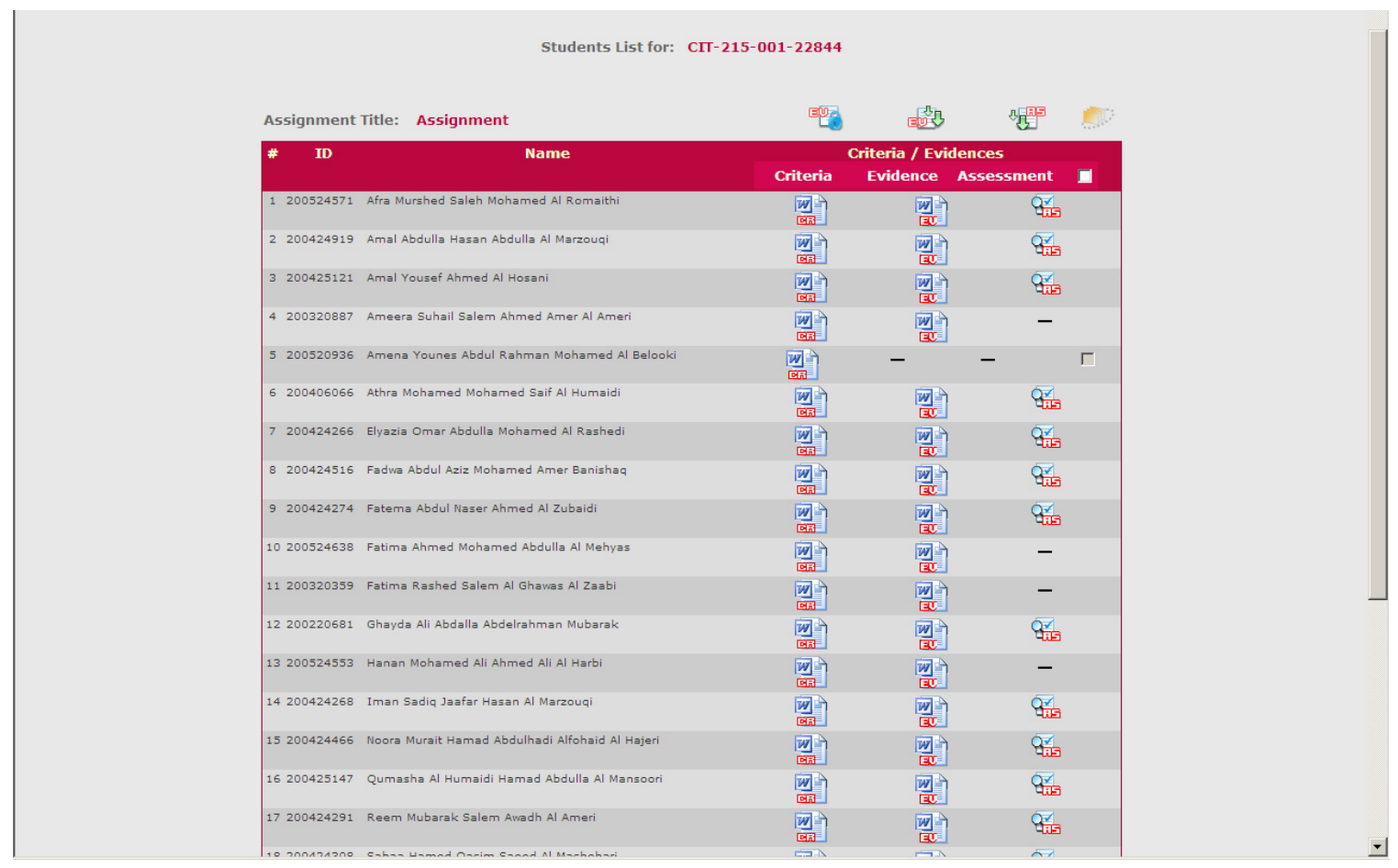

Figure 4: Student list, assessment criteria and evidence 
The e-portfolio for each student can then be displayed by clicking on any specific name allowing a faculty member to review the student's work and complete a scoring rubric. Figure 5 shows a snapshot of the e-portfolio section that describes instructors feedback particular to each student for a given course. This frame contains the assessment criteria document, the piece of evidence submitted by the student, the assessment grade (if any), the particular learning outcome achievement level, and the instructor comments.

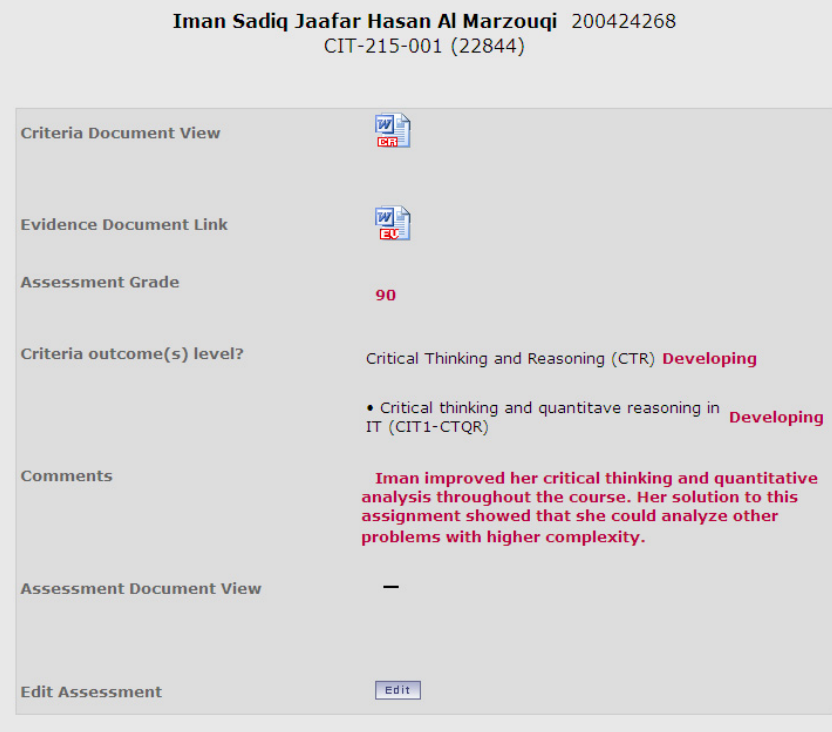

Figure: 5 EAS frame for a specific student

The IT College has accumulated a significant amount of data from the e-portfolio assessment system. The college is using this data to evaluate the effectiveness of learning outcomes across the curriculum.

\section{Conclusions and Future Work}

In this study, an e-portfolio assessment system is introduced to assess major student work towards achieving learning outcomes. Students compile key learning experiences to showcase their work in their e-portfolios. Each e-portfolio includes a variety of digital artifacts, including faculty comments of what students have submitted. At the end of their studies, senior students present the final version of their e-portfolios to a faculty panel and explain the choice of each item and how it links to all college learning outcomes. Finally, faculty members in the college use information generated to assess curricular efficiency and to evaluate the effectiveness of the learning outcomes for each course.

What is needed next is a robust system that can be used for both program assessment and the assessment of individual student work. The next phase of the e-portfolio implementation is to look at the distribution of learning outcomes and students assignments to study the effect of specific outcomes on key courses of the curriculum. Although ZU e-portfolio has accumulated a good amount of data from colleges, the analysis of this data is still under development. If used properly, the reflective aspect of the e-portfolio assessment system will facilitate the advising process, and give their respective colleges' valuable information about student's accomplishments. One important question that needs to be answered is: should we include e-portfolio assessment as part of the official student transcript. 


\section{References}

American Association for Higher Education. (2008). Electronic portfolios: Practices for students, faculty and institutions. Retrieved October 20, 2008, from http://ahe.ital.utexas.edu/electronicportfolios/index.html

Brooks, B. (1997). Beyond teaching and learning paradigms: Trekking into the virtual university. Teaching Sociology, 27, 1-4

Furman, G. (1994), Outcome-based education and accountability. Education and Urban Society, 26 (4), 1316

John Hopkins University. (2008). Electronic portfolio. Retrieved November, 20, 2008 from http://www.cte.jhu.edu/epweb/

Lorenzo, G., \& Ittelson, J. (2005). Demonstrating and assessing student learning with e-portfolios. EDUCAUSE Learning Initiative, July, 1-19.

Mansfield, H. C. (2001). Grade inflation: It's time to face the facts. The Chronicle of Higher Education. Retrieved April 25, 2009 from http://chronicle.com/free/v47/i30/30b02401.htm

Smith, M., \& Winking-Diaz, A. (2004). Increasing students' interactivity in an online course. The Journal of Interactive Online Learning, 2(3), 1-25. Retrieved April 4, 2009 from http://www.ncolr.org/jiol/issues/PDF/2.3.3.pdf

Zayed University. (2008a). The Academic Program Model. Available at http://www.zu.ac.ae/catalog/documents/pdf/2008Catalog.academicProgramModel.pdf

Zayed University. (2008b). Internal report on self-assessment of Zayed University based on accreditation standards of the middle states commission on higher education. Available at http://www.zu.ac.ae 


\section{Appendix}

\section{CIT 215 Computing Foundations Master Course Syllabus Catalog Description:}

This course provides an introduction to the foundations of programming and problem solving. Topics include introduction to algorithms and algorithm design and implementation, number representations, boolean algebra and computing logic, sets and relations, functions, and descriptive and inferential statistics.

\section{Course Objectives:}

Students will be able to demonstrate knowledge and understanding of:

1. The role of algorithms in solutions of computing problems

2. Design of algorithms to solve specific computing problems, and coding simple algorithms in one programming language (e.g. Quick Basic)

3. Numbers representations and conversions used in the computer

4. Sets and relations in computing

5. Logic to reduce equations and build digital circuits

6. Functions and programming

7. Descriptive and inferential statistics

\section{Learning Outcomes:}

\section{Critical Thinking and Quantitative Reasoning (Developing)}

This ZULO is addressed through the activities of analyzing different alternatives for solving problems, learning the difference and similarities between solving problems by hand and using a computer program, and finding solutions to complex problems.

\begin{tabular}{|c|c|c|c|c|c|c|c|c|c|c|}
\hline \multirow[b]{2}{*}{ Outcome } & \multicolumn{5}{|c|}{ ZU Learning Outcomes } & \multicolumn{5}{|c|}{ Major Learning Outcomes } \\
\hline & IT & GA & CTQR & ILC & $\mathrm{TL}$ & PIA & PS & ITA & STP & $\mathrm{TC}$ \\
\hline Development Level & & & D & & & D & D & & & \\
\hline $\begin{array}{l}\text { Primary } \\
\text { Evidence }\end{array}$ & & & $\mathbf{x}$ & & & $\mathrm{X}$ & $\mathbf{X}$ & & & \\
\hline $\begin{array}{l}\text { Secondary } \\
\text { Evidence }\end{array}$ & & & & & & & & & & \\
\hline
\end{tabular}

\section{Course Evidence of Outcome Achievement}

\begin{tabular}{|c|l|}
\hline & \multicolumn{1}{|c|}{ Description of topics that support the learning outcomes } \\
\hline PIA & $\begin{array}{l}\text { Students complete assignments and tests that assess their ability to develop and code pro- } \\
\text { grams. }\end{array}$ \\
\hline CTQR & Students must critically assess their work to locate and correct errors in their program logic. \\
\hline PS & Students solve computing problems using tools that they practice in class. \\
\hline
\end{tabular}

The assignments require the student to show a knowledge and ability in programming fundamentals and algorithm design. They also learn to think critically in debugging assignments for both syntax and logic errors. Students develop solutions to problems and are required to communicate their findings in a professional manner 


\section{Biographies}

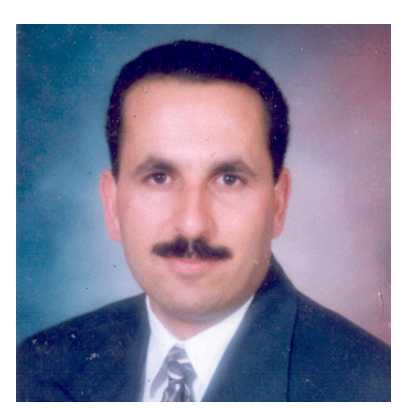

Abdallah Tubaishat is an Associate Professor in the College of Information Technology at Zayed University, United Arab Emirates. He received his $\mathrm{PhD}$ in Software Engineering from Illinois Institute of Technology, IL, USA in 1994. Dr. Tubaishat has around fourteen years of experience in teaching and research. His teaching experience include: Software Engineering, Database and Programming, His research interests include e-learning and software engineering. He has published a book with others entitled "Computer Skills", and has around twenty three Journal and conference publications.

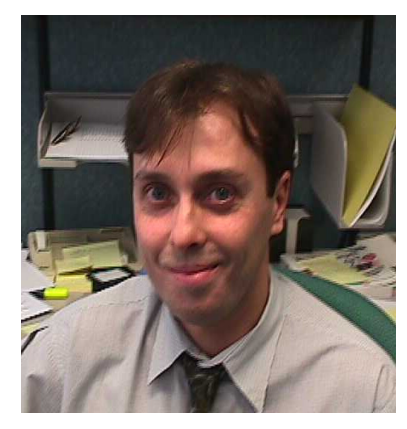

Azzedine Lansari received a $\mathrm{PhD}$ in Bioengineering from North Carolina State University in 1992. From 1992-1998, he was a senior researcher at Computer Sciences Corp. and MANTECH, Inc. He joined Zayed University in August 1998. Currently he is an Associate Professor of Information Technology. His teaching interests include: Computing foundations, systems analysis and design and statistical modeling. His research interests include systems modeling, educational technology and curriculum design.

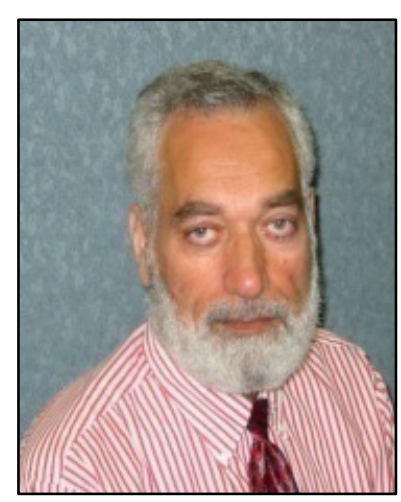

Akram Al-Rawi is a Visiting Professor of Computer Science at McKendree University, Lebanon, IL. He has worked at several academic institutions of which the last three were Zayed University, University of MissouriColumbia, and Columbia College, MO. His teaching interests include programming languages, Digital logic design, Networks and computer architecture. His research interests include computer simulations and curriculum design. He holds certifications in A+, Network+, Security +, i-Net+, Server+, CCNA and CCAI. 